\title{
PENGARUH BUDAYA ORGANISASI, PENGHARGAAN DAN KEPERCAYAAN TERHADAP MOTIVASI BERPRESTASI PEGAWAI DINAS PENDIDIKAN PEMUDA DAN OLAHRAGA KABUPATEN ROKAN HULU
}

\author{
Hardianto \\ Universitas Pasir Pengaraian \\ Jl. Tuanku Tambusai, Rambah, Pasir Pengairan, Rokan Hulu, Riau 28558, Indonesia \\ hardiantocally@gmail.com
}

\begin{abstract}
Abstrak
Tujuan penelitian ini untuk menganalisis besarnya pengaruh budaya organisasi, penghargaan dan kepercayaan terhadap motivasi berprestasi pegawai dinas pendidikan pemuda dan olahraga Kabupaten Rokan Hulu. Survei dilakukan terhadap 75 orang pegawai yang dijadikan sampel penelitian dengan teknik simple random sampling. Pengolahan data dilakukan dengan analisis jalur. Hasil penelitian menunjukkan bahwa: (1) budaya organisasi berpengaruh langsung positif terhadap motivasi berprestasi, (2) penghargaan berpengaruh langsung positif terhadap motivasi berprestasi, (3) kepercayaan berpengaruh langsung positif terhadap motivasi berprestasi, (4) budaya organisasi berpengaruh langsung positif terhadap kepercayaan, (5) penghargaan berpengaruh langsung positif terhadap kepercayaan. Berdasarkan hasil penelitian dapat disimpulkan bahwa untuk meningkatkan motivasi berprestasi pegawai dapat dilakukan dengan meningkatkan budaya organisasi, penghargaan dan kepercayaan. Sementara untuk meningkatkan kepercayaan pegawai dapat dilakukan dengan meningkatkan budaya organisasi dan penghargaan.

Kata Kunci: budaya organisasi, penghargaan, kepercayaan, motivasi berprestasi

\section{THE EFFECT OF ORGANIZATION CULTURE, REWARD, AND TRUST ON ACHIEVEMENT MOTIVATION OF YOUTH AND SPORTS EDUCATION DEPARTMENT OF ROKAN HULU DISTRICT}

\begin{abstract}
The purpose of this study was to analyze the magnitude of the effect of organizational culture, appreciation and trust toward the employees' achievement motivation of Education, Youth and Sports education Ministery of Rokan Hulu Regency. The survey was conducted on 75 employees. Sample was taken by simple Random Sampling Technique. Data analysis was done by path analysis. The results showed that: (1) Organizational culture has a direct positive effect toward achievement motivation, (2) The reward has a direct positive effect toward achievement motivation, (3) Trust has a direct positive effect toward achievement motivation, (4) Organizational culture has a direct positive effect toward the trust, (5) Reward has a positive direct effect toward the trust. Based on the research results could be concluded that to improve employees' achievement motivation could be done by improving organizational culture, appreciation, and trust. Meanwhile, to increase the confidence of employees could be done by improving the organizational culture and appreciation.
\end{abstract}

Keywords: organizational culture, reward, trust, achievement motivation

Permalink/DOI: http://dx.doi.org/10.21831/amp.v6i2.19489 


\section{Pendahuluan}

Pencapaian tujuan organisasi sangat ditentukan oleh anggota organisasi. Begitu juga pada dinas pendidikan pemuda dan olahraga (Disdikpora) Kabupaten Rokan Hulu. Pencapaian tujuan dinas ditentukan oleh para pegawainya. Tujuan disdikpora akan bisa tercapai secara optimal apabila pegawainya memiliki motivasi berprestasi yang tinggi.

Motivasi berprestasi merupakan a social form of motivation involving a competitive desire to meet standards of excellence (Colman, 2001, p. 35). Memiliki motivasi berprestasi akan membuat pegawai bekerja dengan lebih keras agar kerberhasilan kerja bisa diraih. Pegawai yang memiliki motivasi berprestasi akan menampilkan perilaku kerja yang lebih baik bukan hanya sekedar melaksanakan pekerjaan.

Motivasi berprestasi secara sederhana dapat dikatakan sebagai keinginan pegawai melaksanakan pekerjaan dengan sebaik-baiknya dan berupaya memenuhi atau bahkan melebihi target kerja yang ditetapkan. Hal ini sesuai dengan pendapat McClelland (George \& Jones, 2005) yang mengemukakan achievement motivations is the desire to perform challenging tasks well and to meet one own hight standards. Pendapat lainnya tentang motivasi berprestasi dikemukakan Slocum, yaitu "achievement motivation model states that people are motivated according to the strenghtof their desire either to perform (1) in terms of a standard of excellence or (2) to succeed in competitive situation. Characteristices of high achievers are they like to set their own goals, they avoid selecting extremely difficult goals, and prefer moderate goals, (3) they prefers tasks that provide immediete feedback" (Slocum \& Hellriegel, 2009, pp. 134-136).

Berdasarkan kajian pendahuluan, penulis melihat motivasi berprestasi pegawai disdikpora Kabupaten Rokan Hulu perlu ditingkatkan. Beberapa permasalahan yang terlihat diantaranya pegawai dalam melaksanakan pekerjaan terkesan hanya untuk melepaskan tanggung jawab, tanpa ada upaya mewujudkan pekerjaan yang optimal. Selain itu, apabila terdapat tugas yang lebih berat, pegawai mengemukakan kurang bersemangat untuk menyelesaikannya.

Banyak faktor yang diduga mempengaruhi motivasi berprestasi seseorang. Faktor-faktor tersebut diantaranya budaya organisasi, penghargaan dan kepercayaan. Budaya organisasi merupakan $a$ shared set of belief and values within an organization (McShane, Olekalns, \& Travaglione, 2013, p. 446). Budaya organisasi yang positif seperti budaya saling membantu, budaya saling bekerja sama tentunya akan dapat meningkatkan motivasi berprestasi seseorang. Penelitian Tiur Asi Siburian mengemukakan the direct influence of organizational culture on achievement motivation with path coefficients of 0,901 (Siburian, 2013, p. 247). Selanjutnya penelitian dari Kavousipour, Noorafshan, Pourahmad, \& Dehghani-Nazhvani (2015, p. 27) menyatakan The culture of students can affect achievement motivation.

Pengertian budaya organisasi lainnya adalah "organizational culture is the totality of the assumptions, values, norms, and behaviour of employees that create physical and social artefacts of an organization (Sinha, 2008, p. 338). Selanjutnya Robbins, Judge, \& Hasham (2012, p. 577) menyatakan organizational culture is a system of shared meaning held by members that distinguishes the organization from other organizations. Kedua pendapat tersebut menekankan bahwa budaya organisasi merupakan perpaduan norma dan sikap bersama anggota organisasi. Budaya organisasi dapat berupa fisik maupun sosial dan merupakan ciri khas dari organisasi. Setiap organisasi memiliki budaya yang berbeda dengan organisasi lainnya.

Selanjutnya pengertian budaya organisasi dari ahli lain yaitu, organizational culture is a shared set of belief and vakues within an organization (Schermerhorn, Hunt, Uhl-Bien, \& Osborn, 2012, p. 9). Colquit, LePine, \& Wesson (2009, p. 534) menyatakan organizational culture as the shared social knowledge within an organization regarding the rules, norms and values that shape the attitudes and behaviors of its employees.

Budaya organisasi mempengaruhi motivasi berprestasi seseorang dalam bekerja. Widodo (2015, p. 187) mengemukakan bah- 
wa pekerjaan dan lingkungan pekerjaan yang merangsang motivasi pasti disenangi dan dihargai oleh semua orang. Pendapat selanjutnya dari Champoux (2011, p. 160) Champoux yang mengemukakan people acquired the need for achievement through socialization to the values of their culture. He based this conclusion on the results of his extensive studies of the presence of need for achievement concepts and themes in the folklore, mythology, and art of various societies.

Dalam mengembangkan budaya, organisasi pimpinan dapat melakukannya dengan berbagai cara, yaitu pemantapan nilai dasar budaya, melakukan pembinaan, membuat acara rutin, memberikan penilaian dan penghargaan tanggap terhadap masalah internal dan eksternal serta melaksanakan koordinasi dan kontrol (Warsilah \& Wijayanti, 2015, p. 97).

Penghargaan juga mempengaruhi motivasi berprestasi. Penghargaan adalah something of value given to the employee on the basis of the elicited behavioral response; it is meant to reinforce the occurrence of the desired response. Most attention has been paid to the response reward connection (Muchinsky, 2006, p. 397). Adanya penghargaan akan menjadikan seseorang merasa dihargai setelah melakukan pekerjaan. Penghargaan tentu saja akan menjadikan dorongan atau motivasi kepada seseorang untuk melaksanakan pekerjaan dengan lebih lagi. Penelitian Manafi, Mohammadi, \& Hejazi (2015, p. 135) menyatakan environmental factors achievement motivation: Incentives: Including reinforcement and reward mechanism. Penelitian Hossain \& Sultana (2014, p. 191) mengemukakan achievement motivation entails three factors; namely, motive of individual, probability of success of a given task and the incentives or reward given for that task.

Penghargaan juga didefinisikan oleh ahli lain seperti a reward is any good thing given by a community to one of its members in recognition of what that person in particular has done (Woodruff, 2011, p. 11). Pada dasarnya setiap pegawai membutuhkan penghargaan dari organisasinya. Slocum \& Hellriegel (2007, pp. 370-373) menyatakan a reward is an event that a person finds desirable or pleasing.
Rewards which are used by organizations are (1) material rewards: pay, pay raises, bonus, incentive plan, (2) rewards from the task: sense of achievement, jobs with more responsibility, job autonomy/self direction, and performing important task (3) social/interpersonal rewards: praise, developmental feedback, requests for suggestions.

Penghargaan yang tepat dan sesuai akan menjadikan karyawan termotivasi untuk melaksanakan pekerjaan dengan lebih baik. Hal ini dijelaskan oleh Wagner \& Hollenbeck (2010) berikut ini. One way to try to create motivation is through rewards, and perhaps the easiest thing to say to a manager, in theory, is that he or she should "pay for performance" or "link rewards to accomplishment. Tujuan diberikannya penghargaan salah satunya akan dapat mempertahan motivasi karyawan. Pendapat ini dipertegas oleh Griffin \& Moorhead (2014, p. 161) yaitu the purpose of the reward system in most organizations is to attract, re-tain, and motivate qualified employees.

Penghargaan yang diberikan kepada karyawan secara umum dibagi dalam tiga pilihan, yaitu (Fahmi, 2016, pp. 64-65): (a) penghargaan dalam bentuk finansial tunai. Ini diterima langsung oleh karyawan tersebut seperti gaji (salary), bonus, uang lembur dan sejenisnya yang bersifat tunai; (b) penghargaan dalam bentuk finansial tunjangan. Pemberian reward seperti ini dalam bentuk tanggungan biaya kesehatan, biaya melahirkan, uang cuti, jaminan asuransi, biaya pemeliharaan rumah, pengisian pulsa telepon dan sejenisnya; (c) penghargaan dalam bentuk non finansial. Pemberian reward dalam bentuk non-finansial ini seperti kenyamanan bekerja dengan suasana ruangan kantor yang sesuai harapan karyawan.

Kepercayaan merupakan keyakinan seseorang terhadap orang lain ataupun kepada organisasinya. Colquit et al. (2009, pp. 223-224) mengemukakan Trust is defined as the willingness to be vulnerable to an authority based on positive expectations about the authoritys actions and intentions. There are three dimensions of trust: (1) competence, defined as the skills, abilities and areas of expertise that enable an authority to be successful in some specific area, (2) character, conveys an alignment 
between words and deeds - a sense that authorities keep their promises, walk the talk and do what they say they will do. It means that the authorities have integrity- they have honest motives and intentions, (3) benevolence, defined as the belief that the authority wants to do good for the trustor, if authorities are perceived as benevolent, it means that they care for employees, are concerned about their well being, and feel a sense of loyalti to them.

Pegawai yang memiliki kepercayaan terhadap rekan kerja dan pimpinan akan merasa termotivasi untuk melaksanakan pekerjaan dengan lebih baik. Kepemimpinan efektif dapat dibangun dengan komunikasi dan koordinasi yang efektif dengan semua bawahan (Sukendar \& Usman, 2013, p. 293). Kepercayaan pegawai terhadap intitusi atau organsasi akan membuat pegawai berkeyakinan dalam diri untuk bekerja dengan lebih baik. Penelitian Okello \& Gilson (2015, p. 82) menyatakan Workplace trust relationships with colleagues, supervisors and managers, employing organisation and patients directly and indirectly influence HW motivation.

Terdapat lima dimensi dari kepercayaan. Robbins \& Judge (2013, p. 458) mengemukakan trust is a positive expectation that another will not- through words, actions, or decisions- act opportunistically. Evidence has identified five dimensions of trust: (1) integrity refers to honesty and truthfulness, (2) competence encompasses an individuals technical and interpersonal knowledge and skills, (3) concistency relates to an individuals reliability, predictability, and good judgment in handling situations, (4) loyalty is the willingness to protect and save face for another person, and (5) opennes: ready to receive new ideas.

Selanjutnya hal yang sama juga dikemukakan oleh DeJanasz, Dowd, \& Schneider (2009, pp. 33-34), yaitu trust is a multifaceted concept that captures ones faith or belief in the integrity or reliability of another person or thing. Trust is composed of five elements: (1) integrity-honesty and sincerity, (2) competence-knowledge and ability, (3) concistencyconformirty with previous practice, (4) loyalityfaithfulness to ones friends and ideals, (5) opennes-not closed to new ideas, willing to share ideas with others.
Pegawai yang sudah percaya terhadap organisasi tidak akan ragu melakukan yang terbaik dalam pekerjaannya. The most important thing about low Trust is the high price everyone pays for it (Price-Jones, 2010, p. 156). Pendapat lainnya mengemukakan without trust employees may focus on self protectio weakening their willingness to cooperate and collaborate, demaging their motivation (DeJanasz et al., 2009, p. 35).

Budaya organisasi akan mempengaruhi kepercayaan. Pegawai yang bekerja dalam budaya organisasi yang positif akan merasakan percaya terhadap organisasinya. Kepercayaan terhadap organisasi tentu akan meningkatkan kinerja mereka. Institutional trust is malleable, shaped by sociocultural factors and value systems (Hmielowski, Feldman, Myers, Leiserowitz, \& Maibach, 2014, p. 4). Pendapat selanjutnya adalah all the organizational culture functions come together to serve an overarching functionreduction of anxiety and uncertainty in human relationships (Champoux, 2011, p. 79).

Beberapa hasil penelitian juga menunjukkan bahwa budaya organisasi mempengaruhi kepercayaan. Kaur \& Madan (2013, p. 133) mengemukakan Trust is a function of perceived risk; Trust deepens over time and with increased reciprocity; Trust is a matter of degree; Culture affects trust. Selanjutnya penelitian Yusuf (2017, p. 214) yang mengemukakan organizational culture had a direct effect on lecturer's trust.

Penghargaan juga mempengaruhi kepercayaan. Pegawai yang diberikan penghargaan akan percaya terhadap organaisasinya. Hasil penelitian Victor \& Hoole (2017, p. 213) Victor dan Hoole menyebutkan results indicated that there is a moderate-tostrong positive relationship between the three constructs, and that rewards are able to predict trust and engagement. Pendapat lain menyebutkan the results suggest that reward structures have a strong influence on trust, and that the effect is mediated by causal schemas, suspicion effects, and self-perception (Ferrin \& Dirks, 2003).

Berdasarkan permasalahan utama dan teori yang ditemukan, maka penelitian ini akan melihat tentang motivasi berpres- 
tasi pegawai yang dilihat dari faktor-faktor yang mempengaruhinya. Faktor-faktor tersebut adalah budaya organisasi, penghargaan dan kepercayaan. Adapun rumusan permasalahan dalam penelitian ini adalah: (1) pengaruh langsung budaya organisasi terhadap motivasi berprestasi; (2) pengaruh langsung penghargaan terhadap motivasi berprestasi; (3) pengaruh langsung kepercayaan terhadap motivasi berprestasi; (4) pengaruh langsung budaya organisasi terhadap kepercayaan; (5) pengaruh langsung penghargaan terhadap kepercayaan.

Berdasarkan uraian yang telah disampaikan, maka Tujuan penelitian ini adalah untuk menganalisis besarnya pengaruh budaya organisasi, penghargaan dan kepercayaan terhadap motivasi berprestasi. Penelitian ini dilaksanakan di dinas pendidikan pemuda dan olahraga Kabupaten Rokan Hulu.

\section{Metode Penelitian}

Metode yang digunakan dalam penelitian ini adalah metode survey dengan pendekatan kuantitatif. Penelitian ini menggunakan teknik analisis jalur atau path analysis. Studi kausal dalam penelitian ini untuk mengkaji keterkaitan antarvariabel penelitian serta mengukur pengaruh satu variabel terhadap variabel lainnya.
Populasi dalam penelitian ini adalah seluruh pegawai dinas pendidikan pemuda dan olahraga. Jumlah sampel penelitian ditentukan dengan menggunakan rumus Slovin. Berdasarkan hasil perhitungan diketahui sampel berjumlah 75 orang. Pengambilan sampel dilakukan dengan teknik simple random sampling.

Data dikumpulkan dengan menggunakan kuesioner. Kuesioner yang digunakan terdiri dari kuesioner budaya organisasi, kuesioner penghargaan, kuesioner kepercayaan dan kuesioner motovasi berprestasi. Sebelum dijadikan instrumen penelitian, kuesioner tersebut diujicobakan terlebih dahulu untuk menentukan validitas dan reliabilitasnya.

Pengujian validitas dilakukan dengan menggunakan rumus Pearson Product Moment. Pengujian reliabilitas dilakukan dengan rumus Alpha Cronbach. Pola keterikatan antarvariabel dalam penelitian ini disajikan pada Gambar 1.

Analisis data menggunakan teknik analisis data secara deskriptif dan inferensial. Penggunaan teknik deskriptif digunakan untuk memperoleh gambaran karakteristik penyebaran nilai setiap variabel yang diteliti. Analisis inferenssial digunakan untuk menguji hipotesis dengan menggunakan analisis jalur.

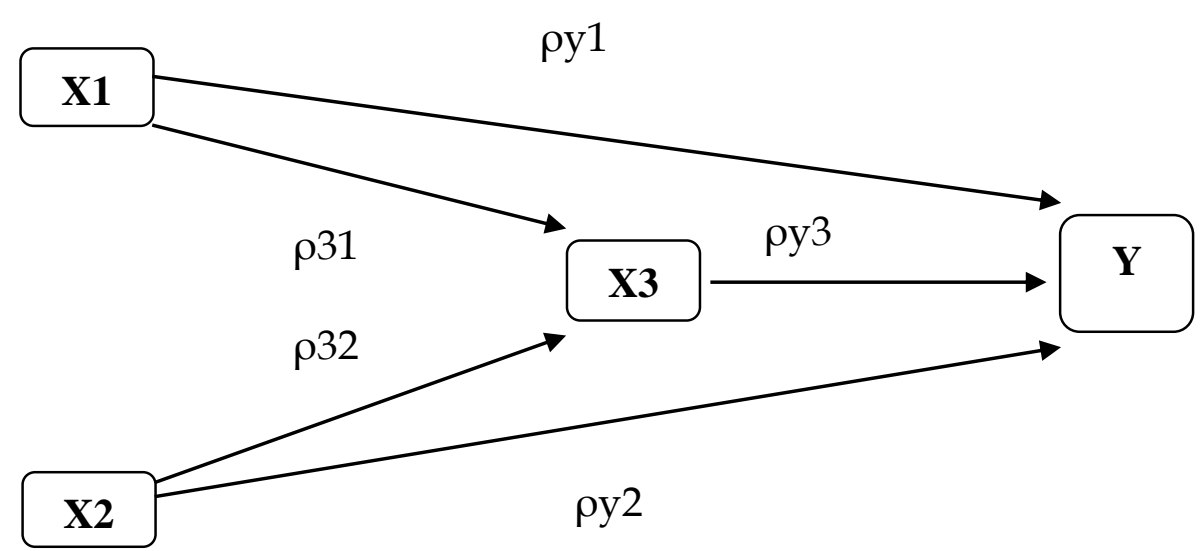

Gambar 1. Model Hipotetik Penelitian

Keterangan :

X1 :Budaya Organisasi

X2 : Penghargaan $\begin{array}{ll}\text { X3 } & \text { : Kepercayaan } \\ \text { Y } & \text { : Motivasi Berprestasi }\end{array}$ 
Analisis deskriptif digunakan dalam hal penyajian data, ukuran sentral dan ukuran penyebaran. Penyajian data menggunakan daftar distribusi dan histogram. Ukuran sentral meliputi Modus, Median dan Mean. Ukuran penyebaran meliputi varians dan simpangan baku.

Pengujian hipotesis dalam penelitian ini menggunakan $a=0,05$. Sebelum melakukan pengujian hipotesis dilakukan terlebih dahulu uji normalitas galat taksiran regresi dengan menggunakan teknik Lillieforse serta uji signifikansi dan uji linieritas model regresi linier sederhana sesuai dengan model hubungan antarvariabel yang dirumuskan dalam kajian teoretik dengan menggunakan analisis varian (ANAVA). Sementara itu, untuk mengukur pengaruh langsung dan tak langsung dari variabel bebas terhadap suatu variabel terikat terlihat dari koefesien jalur.

\section{Hasil Penelitian dan Pembahasan}

Berdasarkan hasil penelitian dapat dirangkum data statistik yang diperoleh sesuai dengan Tabel 1.

Untuk membantu pengolahan data hasil penelitian digunakan Program SPSS versi 20. Berdasarkan hasil pengolahan data penelitian diperoleh hasil akhir sebagaimana terlihat pada Gambar 2.

Pengujian hipotesis dilakukan dengan bantuan program SPSS versi 20. Hasil penelitiannya dapat dilihat pada Tabel 2, Tabel 3 dan Tabel 4.

Tabel 1. Rangkuman Data Statistik Penelitian

\begin{tabular}{lcccc}
\hline & $\begin{array}{c}\text { Budaya } \\
\text { Organisasi }\end{array}$ & Penghargaan & Kepercayaan & $\begin{array}{c}\text { Motivasi } \\
\text { Berprestasi }\end{array}$ \\
\hline $\mathrm{N} \quad$ Valid & 75 & 75 & 75 & 75 \\
$\quad$ Missing & 0 & 0 & 0 & 0 \\
Mean & 105.81 & 108.68 & 102.88 & 108.01 \\
Std. Error of Mean & 1.215 & 1.237 & .597 & 1.456 \\
Median & 107.00 & 109.00 & 102.00 & 110.00 \\
Mode & 99 & 100 & 102 & 103 \\
Std. Deviation & 10.524 & 10.714 & 5.167 & 12.609 \\
Variance & 110.748 & 114.788 & 26.702 & 158.986 \\
Range & 55 & 45 & 30 & 52 \\
Minimum & 75 & 83 & 90 & 80 \\
Maximum & 130 & 128 & 120 & 132 \\
Sum & 7936 & 8151 & 7716 & 8101 \\
\hline
\end{tabular}

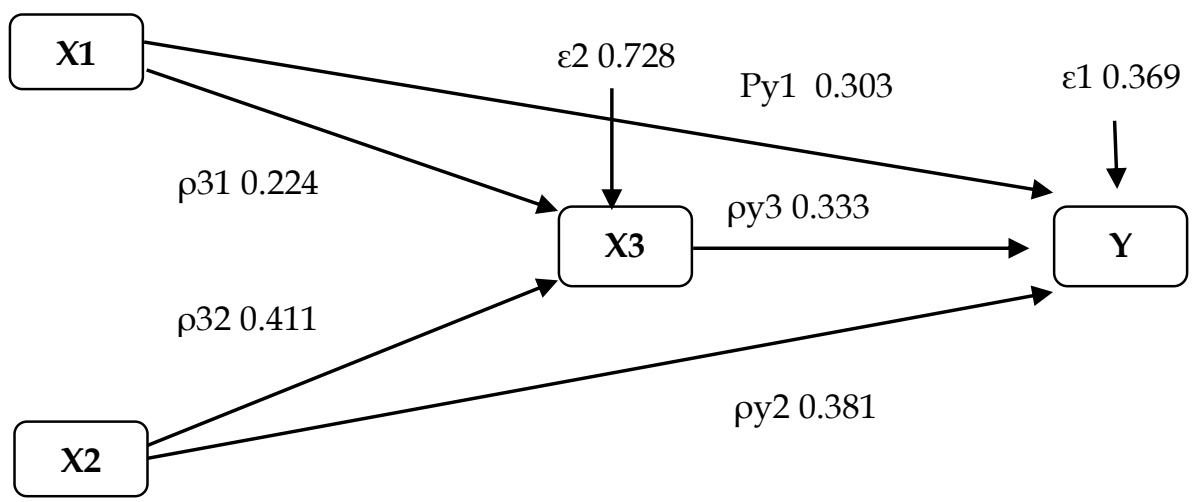

Gambar 2. Koefesien Jalur Hasil Penelitian

Keterangan:

$\begin{array}{llll}\text { X1 } & \text { : Budaya Organisasi } & \text { X3 } & \text { : Kepercayaan } \\ \text { X2 } & \text { : Penghargaan } & \text { Y } & \text { : Motivasi Berprestasi }\end{array}$


Tabel 2. Koefesien Regresi Variabel Dependen Motivasi Berprestasi

\begin{tabular}{rccccc}
\hline \multicolumn{7}{l}{ Model } & \multicolumn{2}{c}{ Unstandardized } & \multicolumn{2}{c}{$\begin{array}{c}\text { Standardized } \\
\text { Coefficients }\end{array}$} & $\begin{array}{c}\text { Coefficient } \\
\text { Beta }\end{array}$ & $\mathrm{t}$ & Sig. \\
\hline Budaya Organisasi & .363 & .096 & .303 & -3.252 & .002 \\
Penghargaan & .448 & .101 & .381 & 4.766 & .000 \\
Kepercayaan & .813 & .214 & .333 & 3.804 & .000 \\
\end{tabular}

Tabel 3. Koefesien Regresi variabel Dependen Kepercayaan

\begin{tabular}{|c|c|c|c|c|c|}
\hline \multirow[b]{2}{*}{ Model } & \multicolumn{2}{|c|}{$\begin{array}{l}\text { Unstandardized } \\
\text { Coefficients }\end{array}$} & \multirow{2}{*}{$\begin{array}{c}\text { Standardized } \\
\text { Coefficient } \\
\text { Beta }\end{array}$} & \multirow[b]{2}{*}{$\mathrm{t}$} & \multirow[b]{2}{*}{ Sig. } \\
\hline & $\mathrm{B}$ & Std. Error & & & \\
\hline Constant & 48.927 & 4.737 & & 10.330 & .000 \\
\hline Budaya Organisasi & .110 & .052 & .224 & 2.137 & .036 \\
\hline Penghargaan & .198 & .051 & .411 & 3.917 & .000 \\
\hline
\end{tabular}

Tabel 4. Kesimpulan Pengaruh Variabel X1, X2, X3 terhadap Y

\begin{tabular}{ccccc}
\hline Model & $\mathrm{R}$ & R Square & $\begin{array}{c}\text { Adjusted R } \\
\text { Square }\end{array}$ & $\begin{array}{c}\text { Std. Error of } \\
\text { the Estimate }\end{array}$ \\
\hline 1 & .777 & .604 & .587 & 8.100 \\
\hline
\end{tabular}

Berdasarkan Gambar dan Tabel tersebut dapat diketahui bahwa penelitian ini menunjukkan sebagai berikut.

Budaya Organisasi Berpengaruh Langsung Positif terhadap Motivasi Berprestasi

Ini dapat dilihat dari koefesien jalur budaya organisasi (X1) ke motivasi berprestasi (Y) atau py1 sebesar 0,303 signifikan pada a $=0.05$ yang berarti koefesien jalur adalah signifikan. Hal ini menunjukkan bahwa $\mathrm{HO}$ ditolak dan $\mathrm{H} 1$ diterima, sehingga dapat dinyatakan pengaruh langsung positif budaya organisasi terhadap motivasi berprestasi. Artinya setiap kenaikan satu satuan pada variabel eksogen budaya organisasi akan menyebabkan kenaikan sebesar 0,303 atau $30,3 \%$ pada variabel endogen motivasi berprestasi.

Untuk meningkatkan motivasi berprestasi perlu ditingkatkan pula budaya organisasi. Budaya organisasi merupakan faktor yang paling kuat dalam meningkatkan motivasi. Hal ini dijelaskan oleh Mullins (2006, p. 187) Mullins nine key motivating factors that also forn the basis of cultural assesment

... (9) internalization- of cultural beliefs and values. Internalization determines our attitude, convictions and behaviors, and is the most powerful and permanent of the nine motivating factor.

Penghargaan Berpengaruh Langsung Positif terhadap Motivasi Berprestasi

Ini dapat dilihat dari koefesien jalur peghargaan $(X 2)$ ke motivasi berprestasi $(Y)$ atau $\rho y 2$ sebesar 0,381 signifikan pada $\alpha=$ 0.05 yang berarti koefesien jalur adalah signifikan. Hal ini menunjukkan bahwa $\mathrm{H} 0$ ditolak dan $\mathrm{H} 1$ diterima, sehingga dapat dinyatakan pengaruhlangsung positif penghargaan terhadap motivasi berprestasi. Artinya setiap kenaikan satu satuan pada variabel eksogen penghargaan akan menyebabkan kenaikan sebesar 0,381 atau 38,1\% pada variabel endogen motivasi berprestasi.

Motivasi berprestasi dapat ditingkatkan dengan memberikan penghargaan yang sesuai berdasarkan hasil pekerjaan. Penghargaan tidak hanya berupa uang tetapi dapat berupa bentuk lain. Financial incentives may be more motivating in the short term, in the long run, nonfinancial incentives are more motivating (Robbins \& Judge, 2013, p. 269). 
Kepercayaan Berpengaruh Langsung Positif terhadap Motivasi Berprestasi.

Ini dapat dilihat dari koefesien jalur kepercayaan (X3) ke motivasi berprestasi $(Y)$ atau $\rho y 3$ sebesar 0,333 signifikan pada a $=0.05$ yang berarti koefesien jalur adalah signifikan. Hal ini menunjukkan bahwa $\mathrm{HO}$ ditolak dan H1 diterima, sehingga dapat dinyatakan pengaruh langsung positif kepercayaan terhadap motivasi berprestasi. Artinya setiap kenaikan satu satuan pada variabel eksogen kepercayaan akan menyebabkan kenaikan sebesar 0,333 atau 33,3\% pada variabel endogen motivasi berprestasi.

Motivasi berprestasi dapat ditingkatkan dengan meningkatkan rasa kepercayaan. Pegawai yang sudah percaya terhadap organisasi akan termotivasi untuk bekerja dengan lebih giat. Kepercayaan karyawan terhadap pimpinan akan sangat membantu meningkatkan motivasi berprestasinya. Employees identify with and feel obliged to work for an organization only when they trust its leader (Rousseau)

Budaya Organisasi Berpengaruh Langsung Positif terhadap Kepercayaan

Ini dapat dilihat dari koefesien jalur budaya organisasi (X1) ke kepercayaan (X3) atau $\rho 31$ sebesar 0,224 signifikan pada $\alpha=$ 0.05 yang berarti koefesien jalur adalah signifikan. Hal ini menunjukkan bahwa $\mathrm{H} 0$ ditolak dan $\mathrm{H} 1$ diterima, sehingga dapat dinyatakan pengaruh langsung positif budaya organisasi terhadap kepercayaan. Artinya setiap kenaikan satu satuan pada variabel eksogen budaya organisasi akan menyebabkan kenaikan sebesar 0,224 atau 22,4\% pada variabel endogen kepercayaan.

Kepercayaan pegawai terhadap organisasi dapat ditingkatkan dengan memba- ngun budaya organisasi yang positif. Budaya organisasi akan dapat mempe-ngaruhi perilaku anggota organisasi, salah satu nya kepercayaan. Organizational culture sometimes called corporate culture, is a system of shared beliefs and values that develops whitin and organization and guides the behavior of its members (Kinicki \& Williams, 2011, p. 236).

Selain dapat meningkatkan kepercayaan, budaya organisasi juga akan mempengaruhi kompetensi. Hasil penelitian secara parsial terdapat pengaruh positif dan signifikan variabel budaya organisasi terhadap kompetensi guru (Syakir \& Pardjono, 2015, p. 236).

Penghargaan Berpengaruh Langsung Positif terhadap Kepercayaan

Ini dapat dilihat dari koefesien jalur penghargaan (X2) ke kepercayaan (X3) atau 032 sebesar 0,411 signifikan pada $\alpha=0.05$ yang berarti koefesien jalur adalah signifikan. Hal ini menunjukkan bahwa $\mathrm{H0}$ ditolak dan $\mathrm{H} 1$ diterima, sehingga dapat dinyatakan pengaruh langsung positif penghargaan terhadap kepercayaan. Artinya setiap kenaikan satu satuan pada variabel eksogen penghargaan akan menyebabkan kenaikan sebesar 0,411 atau $41,1 \%$ pada variabel endogen kepercayaan.

Penghargaan yang tepat juga akan meningkatkan kepercayaan pegawai. Sistem penghargaan memiliki banyak pengaruh termasuk membangun kepercayaan. Reward management policy and practice are subject to a number of influences (Armstrong, 2007, p. 12).

Untuk mempermudah pemahaman terhadap hasil uji hipotesis yang telah dibahas, rangkuman hasil penelitian disajikan pada Tabel 5.

Tabel 5. Rekapitulasi hasil Pengujian Hipotesis Penelitian

\begin{tabular}{|c|c|c|c|c|c|c|c|}
\hline No & & efesier & Jalur & $\begin{array}{c}\mathrm{t} \\
\text { hitung }\end{array}$ & $\begin{array}{c}\mathrm{t} \\
\text { tabel }\end{array}$ & Arti & Kesimpulan \\
\hline 1 & oy1 & 0.303 & $a=0,05$ & 3.766 & 1.661 & Signifikan & Berpengaruh positf dan langsung \\
\hline 2 & рy2 & 0.381 & $a=0,05$ & 4.433 & 1.661 & Signifikan & Berpengaruh positf dan langsung \\
\hline 3 & $\rho y 3$ & 0.333 & $a=0,05$ & 3.804 & 1.661 & Signifikan & Berpengaruh positf dan langsung \\
\hline 4 & $\rho 31$ & 0.224 & $\alpha=0,05$ & 2.122 & 1.661 & Signifikan & Berpengaruh positf dan langsung \\
\hline 5 & $\rho 32$ & 0.411 & $\alpha=0,05$ & 3.889 & 1.661 & Signifikan & Berpengaruh positf dan langsung \\
\hline
\end{tabular}




\section{Simpulan}

Berdasarkan hasil penelitian dapat ditarik beberapa kesimpulan, yaitu sebagai berikut. Pertama, Budaya organisasi berpengaruh langsung positif terhadap motivasi berprestasi. Artinya budaya organisasi dapat meningkatkan motivasi berprestasi pegawai dinas pendidikan pemuda dan olahraga Kabupaten Rokan Hulu. Kedua, penghargaan berpengaruh langsung positif terhadap motivasi berprestasi. Artinya penghargaan dapat meningkatkan motivasi berprestasi pegawai dinas pendidikan pemuda dan olahraga Kabupaten Rokan Hulu.

Ketiga, kepercayaan berpengaruh langsung positif terhadap motivasi berprestasi. Artinya kepercayaan dapat meningkatkan motivasi berprestasi pegawai dinas pendidikan pemuda dan olahraga Kabupaten Rokan Hulu. Keempat, budaya organisasi berpengaruh langsung positif terhadap kepercayaan. Artinya budaya organisasi dapat meningkatkan kepercayaan pegawai dinas pendidikan pemuda dan olah raga Kabupaten Rokan Hulu. Keempat, penghargaan berpengaruh langsung positif terhadap kepercayaan. Artinya penghargaan dapat meningkatkan kepercayaan pegawai dinas pendidikan pemuda dan olahraga Kabupaten Rokan Hulu. Kelima, variabel penghargaan memiliki pengaruh langsung positif paling besar terhadap motivasi berprestasi dibandingkan variabel lain, yaitu budaya organisasi dan kepercayaan. Variabel penghargaan juga memiliki pengaruh langsung positif lebih besar dari variabel budaya organisasi terhadap kepercayaan.

Beberapa saran yang dapat diberikan setelah penelitian ini adalah sebagai berikut. Pertama, kepada pimpinan di lingkungan dinas pendidikan pemuda dan olahraga Kabupaten Rokan Hulu untuk lebih meningkatkan pemberian penghargaan kepada para pegawai, karena peningkatan penghargaan dapat meningkatkan motivasi berprestasi pegawai dan juga meningkatkan kepercayaan mereka. Selain itu, perlu juga untuk meningkatkan budaya organisasi yang positif dan kepercayaan pegawai. Peningkatan dua variabel ini juga akan meningkatkan motivasi berprestasi yang pada akhirnya tentu akan mengoptimalisasikan pencapaian tujuan dinas pendidikan pemuda dan olahraga.

Kedua, disarankan kepada para pegawai untuk selalu menampilkan perilaku yang positif sehingga akan menjadikan budaya organisasi yang positif yang pada akhirnya dapat meningkatkan motivasi berprestasi.

\section{Daftar Pustaka}

Armstrong, M. (2007). A Handbook of employee reward management and practice. United Kingddom: Kogan Page.

Champoux, J. E. (2011). Organizational behavior: integrating individuals, groups, and organization (4th ed.). New York: Routledge.

Colman, A. M. (2001). A dictionary of psychology. New York: Oxford University Press Inc.

Colquit, J., LePine, J. A., \& Wesson, M. J. (2009). Organizational behavior improving performance and commitment in the workplace. Boston: McGraw Hill/Irwin.

DeJanasz, S. C., Dowd, K. O., \& Schneider, B. Z. (2009). Interpersonal skills in organizations. Boston: McGraw Hill/Irwin.

Fahmi, I. (2016). Manajemen sumber daya manusia teori dan aplikasi. Bandung: Alfabeta.

Ferrin, D. L., \& Dirks, K. T. (2003). The use of rewards to increase and decrease trust: mediating processes and differential effects. Singapore Management University.

George, J. M., \& Jones, G. R. (2005). Understanding and managing organizational behavior. New Jersey: Prentice Hall.

Griffin, R. W., \& Moorhead, G. (2014). Organizational behavior: managing people and organizations (11th ed.). South- 
Western College Pub.

Hmielowski, J. D., Feldman, L., Myers, T. A., Leiserowitz, A., \& Maibach, E. (2014). An attack on science? Media use, trust in scientists, and perceptions of global warming. Public

Understanding of Science, 23(7), 866883.

https:// doi.org/10.1177/09636625134 80091

Hossain, S., \& Sultana, S. (2014). Factors affecting achievement motivation: a study on the selected industries of Bangladesh. ASA University Review, $8(2)$.

Kaur, B., \& Madan, S. (2013). Factors influencing trust in online shopping: an Indian consumer's perspective. European Journal of Business and Management, 5(29).

Kavousipour, S., Noorafshan, A., Pourahmad, S., \& DehghaniNazhvani, A. (2015). Achievement motivation level in students of Shiraz University of Medical Sciences and its influential factors. Journal of Advances in Medical Education \& Professionalism, 3(1), 26-32. Retrieved from https://www.ncbi.nlm.nih.gov/pmc/ articles/PMC4291505/

Kinicki, A., \& Williams, B. (2011). Management a practical introduction. New York: McGraw Hill.

Manafi, D., Mohammadi, S. H. M., \& Hejazi, S. Y. (2015). Factor analysis of student's achievement motivation variables (case study: agricultural Ms.C student in Tehran University). International Journal of Advanced Biological and Biomedical Research, 3(2), 134-138. Retrieved from http://www.ijabbr.com/article_12774 .html

McShane, S. L., Olekalns, M., \& Travaglione, T. (2013). Organizational behavior emerging knowledge global insights. New York: McGraw Hill.
Muchinsky, P. M. (2006). Psychology applied to work (8th ed.). Thomas Publishing Co.

Mullins, L. J. (2006). Essentials of organizational behavior. England: Prentice Hall.

Okello, D. R. O., \& Gilson, L. (2015). Exploring the influence of trust relationships on motivation in the health sector: a systematic review. Human Resources for Health, 13(1), 16. https:// doi.org/10.1186/s12960-0150007-5

Price-Jones, J. (2010). Happines at work maximing yourpsychological capital your success. Wiley Blacwell.

Robbins, S. P., \& Judge, T. A. (2013). Organizational behavior (15th ed.). London: Pearson Education Ltd.

Robbins, S. T., Judge, T. A., \& Hasham, E. S. (2012). Organizational behavior. Harlow: Pearson Education Limited.

Schermerhorn, J. R., Hunt, J. G., Uhl-Bien, M., \& Osborn, R. N. (2012). Organizational behavior (12th ed.). Wiley Custom Learning Solutions.

Siburian, T. A. (2013). The effect of interpersonal communication, organizational culture, job satisfaction, and achievement motivation to organizational commitment of state high school teacher in the District Humbang Hasundutan, North Sumatera, Indonesia. International Journal of Humanities and Social Science, 3(12). Retrieved from http://www.ijhssnet.com/journal/in dex/1916

Sinha, J. B. P. (2008). Culture and organizational behaviour. SAGE Publications Pvt. Ltd.

Slocum, J. W., \& Hellriegel, D. (2007). Fundamental of organization behavior. Mason: Thomson South Western.

Slocum, J. W., \& Hellriegel, D. (2009). Principles of organization behavior. 
Canada Cengage: Learning South Western.

Sukendar, S., \& Usman, H. (2013). Karakteristik kepemimpinan efektif kepala sekolah SMP Negeri 1 Banguntapan. Jurnal Akuntabilitas Manajemen Pendidikan, 1(2). Retrieved from https://journal.uny.ac.id/index.php/ jamp/article/view/2400

Syakir, M. J., \& Pardjono, P. (2015). Pengaruh kepemimpinan kepala sekolah, motivasi kerja dan budaya organisasi terhadap kompetensi guru. Jurnal Akuntabilitas Manajemen Pendidikan, 3(2). Retrieved from https://journal.uny.ac.id/index.php/ jamp/article/view/6339

Victor, J., \& Hoole, C. (2017). The influence of organisational rewards on workplace trust and work engagement. SA Journal of Human Resource Management, 15. https://doi.org/10.4102/sajhrm.v15i0 .853

Wagner, J. A., \& Hollenbeck, J. R. (2010). Organizational behavior securing competitive advantage. New York: Routledge.

Warsilah, W., \& Wijayanti, W. (2015). Peran kepala sekolah dalam pengembangan budaya sekolah di UPT SD Kecamatan Moyudan Kabupaten Sleman. Jurnal Akuntabilitas Manajemen Pendidikan, 3(1). Retrieved from https://journal.uny.ac.id/index.php/ jamp/article/view/6273

Widodo, S. E. (2015). Manajemen pengembangan sumber daya manusia (Yogyakarta). Pustaka Pelajar.

Woodruff, P. (2011). The ajak dilemma justice, fairness and rewards. New York: Oxford University Press.

Yusuf, F. A. (2017). The impact of organizational culture, leadership, job satisfaction and trust towards lecture's organizational commitment of the Private Universities in Serang Regency Indonesia. International Journal of Human Resource Studies, 7(1). https:// doi.org/10.5296/ijhrs.v7i1.11 043 